\title{
Bacterial utilization of dissolved free amino acids, dissolved combined amino acids and ammonium in the Delaware Bay estuary: effects of carbon and nitrogen limitation
}

\author{
Mathias Middelboe $^{1, *}$, Niels Henrik Borch ${ }^{2}$, David L. Kirchman ${ }^{2}$ \\ ${ }^{1}$ Freshwater Biological Laboratory, University of Copenhagen, Helsingersgade 51, DK-3400 Hillerød, Denmark \\ ${ }^{2}$ University of Delaware, College of Marine Studies, 700 Pilottown Road, Lewes, Delaware 19958, USA
}

\begin{abstract}
The contribution of dissolved free amino acids (DFAA), dissolved combined amino acids (DCAA) and ammonium to the $\mathrm{C}$ and $\mathrm{N}$ requirements of bacterioplankton was examined in batch cultures enriched with various sources of $\mathrm{C}$ and $\mathrm{N}$. DFAA sustained up to 14 and $34 \%$ of the $\mathrm{C}$ and $\mathrm{N}$ requirements, respectively, during exponential growth. DCAA constituted less than $10 \%$ of the $\mathrm{C}$ demand in all cultures during exponential growth and up to $24 \%$ of the $\mathrm{N}$ demand in $\mathrm{N}$-limited cultures. In C-limited cultures DFAA, DCAA, and $\mathrm{NH}_{4}{ }^{+}$constituted 37 to $62 \%, 4$ to $10 \%$ and 27 to $59 \%$ of total $\mathrm{N}$ uptake (DFAA + DCAA $+\mathrm{NH}_{4}{ }^{+}$) during exponential growth. In nitrogen-limited cultures the corresponding values were 78,14 , and $8 \%$ of total $N$ uptake. During the stationary phase the importance of DCAA as a $\mathrm{C}$ and $\mathrm{N}$ source increased as DFAA and $\mathrm{NH}_{4}{ }^{+}$concentrations decreased. In addition to allowing us to examine the contribution of various compounds to supporting bacterial production, our data on uptake and concentrations suggest that bacteria release free and combined amino acids, especially during the stationary phase.
\end{abstract}

KEY WORDS: DCAA - DFAA - Ammonium - Bacterial utilization $\cdot \mathrm{C}$ - and N-limitation

\section{INTRODUCTION}

Bacterial extracellular hydrolysis of polymeric organic compounds and subsequent utilization of the produced mono- and oligomers have been studied intensively during recent years (e.g. Hoppe et al. 1988, Billen 1991). Despite much work on dissolved combined amino acids (DCAA) in particular, the importance of these compounds in supporting bacterial $\mathrm{C}$ and $\mathrm{N}$ demand is not clearly resolved. Several batch culture studies with natural assemblages of bacteria have found dissolved free amino acids (DFAA) and $\mathrm{NH}_{4}{ }^{+}$to be the primary $\mathrm{N}$ sources for bacteria (Keil \&

\footnotetext{
- Present address: Microbiology Section, Department of Ecology and Molecular Biology, The Royal Veterinary and Agricultural University, Rolighedsvej 21, DK-1958 Frederiksberg C. Denmark.E-mail: mathias.middelboe@ecol.kvl.dk
}

Kirchman 1991, 1993, Jørgensen et al. 1993). In these studies utilization of DCAA generally constituted $<10 \%$ of $\mathrm{C}$ and $\mathrm{N}$ uptake by bacteria. Other studies, however, found that DCAA may contribute substantially to bacterial growth (Coffin 1989, Tupas \& Koike 1990, Simon \& Rosenstock 1992, Rosenstock \& Simon 1993, Jørgensen et al. 1994, Kroer et al. 1994).

In Lake Constance (W Europe), Simon \& Rosenstock (1992) and Rosenstock \& Simon (1993) observed that DCAA utilization may explain $>100 \%$ of bacterial production during periods of low in situ concentrations of DFAA. In support of these results, Keil \& Kirchman (1993) found a negative correlation between DFAA concentration and the importance of proteins for bacterial growth in coastal waters and suggested that protein utilization was partially controlled by the concentration of DFAA. A similar correlation between DFAA. and DCAA concentrations was observed in a cross- 
system study by Kroer et al. (1994), who argued that differences in the DCAA:DFAA ratio may determine their relative significance for bacterial growth. Moreover, Keil \& Kirchman (1991) suggested that DCAA constituted an increasingly important substrate for bacteria, as DFAA were depleted from the cultures. Thus, it appears that different $\mathrm{C}$ and $\mathrm{N}$ sources are utilized in an order of priority by a bacterial assemblage. and that DCAA does not contribute significantly to bacterial growth as long as DFAA or $\mathrm{NH}_{4}{ }^{+}$along with a simple $C$ source are available.

In this study we examined the relative importance of DFAA, DCAA and $\mathrm{NH}_{4}{ }^{+}$for bacterial $\mathrm{C}$ and $\mathrm{N}$ demand during periods of $\mathrm{N}$ and $\mathrm{C}$ limitation of bacterial growth in the Delaware Bay estuary (Atlantic coast, USA).

\section{MATERIALS AND METHODS}

Experimental design. Two bacterial batch culture experiments were carried out on October 4 (Expt 1) and 8 (Expt 2), 1993, with water samples collected just before high tide outside the surf zone at Lewes Beach, Delaware Bay. Batch cultures were prepared with $80 \%$ $0.2 \mu \mathrm{m}$-filtered and $20 \% 0.8 \mu \mathrm{m}$-filtered water; $142 \mathrm{~mm}$ polycarbonate filters (Nuclepore) and gravity filtration were used. Each experiment consisted of 3 cultures enriched with inorganic or organic compounds and 1 control culture without additions. In Expt 1 the compounds were added immediately before incubation and the cultures received $10 \mu \mathrm{M} \mathrm{NH}_{4}{ }^{+}, 5 \mu \mathrm{M}$ glucose, or both. Expt 2 was started as 1 culture until $21 \mathrm{~h}$ of incubation after which it was divided into 4 subcultures and amended with $10 \mu \mathrm{M} \mathrm{NH}_{4}{ }^{+}, 5 \mu \mathrm{M}$ glucose, or an amino acid mixture containing $400 \mathrm{nM}$ of each of the 12 most common amino acids found in the water samples ( $5 \mu \mathrm{M}$ total). Incubations were in $5 \mathrm{l}$ polypropylene bottles in the dark and at in situ temperature.

Bacterial abundance. Bacterial abundance was estimated by using acridine orange epifluorescent microscopy (Hobbie et al. 1977), and the bacterial specific growth rate $(\mu)$ was calculated from changes in abundance.

Dissolved free amino acids (DFAA). Concentration of individual amino acids was measured in $0.2 \mu \mathrm{m}$ filtered subsamples (Acrodisc, Gelman Sciences, MI, USA) by high-performance liquid chromatography (HPLC) after derivatization with o-phthaldialdehyde (OPA) according to Lindroth \& Mopper (1979), modified according to Jørgensen et al. (1993). Analytical precision was about $5 \%$.

The turnover of amino acids was measured by incubation of subsamples with a mixture of $15^{3} \mathrm{H}$-labelled amino acids (Amersham) with an average specific activity of $51 \mathrm{Ci} \mathrm{mmol}^{-1}$. Twenty-five $\mu \mathrm{Ci}$ was added to $20 \mathrm{ml}$ triplicate subsamples (plus 1 control killed with $2 \%$ formaldehyde) which were incubated for 20 to $60 \mathrm{~min}$. Incubations were stopped with formaldehyde ( $2 \%$ final concentration) and samples were filtered through $0.2 \mu \mathrm{m}$ cellulose nitrate filters (Sartorius) and rinsed 4 times with Milli-Q water. The filters were then dissolved for $30 \mathrm{~min}$ in ethyl acetate followed by the addition of scintillation cocktail and radioassay by liquid scintillation counting. Respiration of ${ }^{3} \mathrm{H}$-labelled amino acids during incubation was measured by distillation of the $0.2 \mu \mathrm{m}$ filtrates (duplicates + killed control). The filtrate was heated to $80^{\circ} \mathrm{C}$ and distilled under vacuum, and ${ }^{3} \mathrm{H}_{2} \mathrm{O}$ in 3 to $5 \mathrm{ml}$ distillate was radioassayed. Bacterial respiration was measured once during the exponential (20 to $21 \mathrm{~h}$ ) and once during the stationary phase (50 to $60 \mathrm{~h}$ ) in all cultures.

Dissolved combined amino acids (DCAA). To measure concentrations of DCAA, $750 \mu$ sample was freeze dried and hydrolyzed in the vapor phase under $\mathrm{N}$ atmosphere for $20 \mathrm{~min}$ at $150^{\circ} \mathrm{C}$ in a microwave oven (N. O. G. Jørgensen unpubl.). Samples were then redissolved in a borate buffer at $\mathrm{pH}>10$ to obtain optimal OPA reaction and quantified by use of HPLC. Milli-Q water treated as samples were used as blanks; these always contained $<10 \%$ of sample concentration.

The turnover of DCAA was estimated by use of the fluorogenic substrate analog L-leucine-4-methylcoumarinylamide hydrochloride (Leu-MCA), according to Hoppe et al. $(1988,1993)$. Leu-MCA is hydrolyzed by the bacterial extracellular enzyme leucine aminopeptidase, and is believed to mimic natural peptides (Hoppe et al. 1988). The turnover of Leu-MCA was used as an estimate of the turnover rate for all proteins. Triplicate $1 \mathrm{ml}$ subsamples were incubated with $500 \mathrm{nM}$ Leu-MCA (final concentration) for 3 to $5 \mathrm{~h}$, and Leu-MCA turnover rate was calculated from the increase in fluorescence as the non-fluorescent Leu-MCA was hydrolyzed to the highly fluorescent 7 -amino-4-methyl-coumarin (AMC). Background fluorescence at time zero was measured for each triplicate sample. A Spectrovision FD-100 fluorometer was used for fluorescence measurements. The increase in fluorescence was linear with time for the incubation times used. The duration of the Leu-MCA incubations was determined by the appearance of a significant fluorescence signal. Total DCAA hydrolysis was estimated from concurrent measurements of Leu-MCA turnover rate and from the decrease in DCAA concentrations.

Ammonium. The ammonium concentration was measured with an Alpkem autoanalyzer using standard procedures. 


\section{RESULTS}

\section{Bacterial abundance and growth rate}

In Expt 1 bacterial abundance increased exponentially during the first $30 \mathrm{~h}$, then remained fairly constant until 55 to $70 \mathrm{~h}$ when the abundance started to decrease (Fig. 1A). The addition of glucose increased the maximum bacterial abundance from $2.5 \times 10^{6}$ cells $\mathrm{ml}^{-1}$ (control) to about $4.5 \times 10^{6}$ cells $\mathrm{ml}^{-1}$ Bacterial growth rate (Fig. 1B) increased during the first $30 \mathrm{~h}$ to maximum rates of 0.08 to $0.11 \mathrm{~h}^{-1}$ in cultures with glucose additions and 0.05 to $0.07 \mathrm{~h}^{-1}$ in cultures without added glucose.

In Expt 2 the control culture had a lower maximum bacterial abundance $\left(1.7 \times 10^{6}\right.$ cells $\mathrm{ml}^{-1}$ after $45 \mathrm{~h}$; Fig. 1C) and lower maximum growth rate
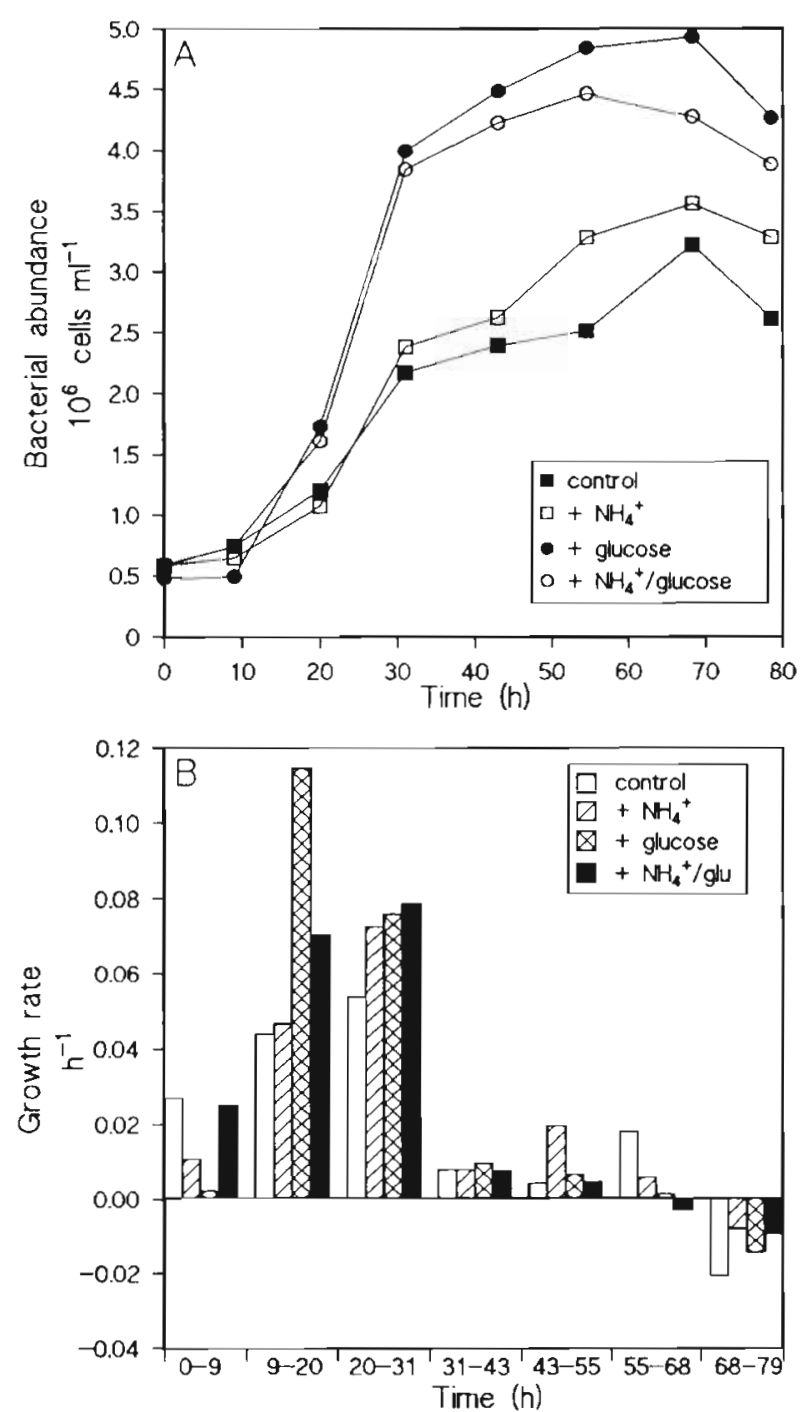

(0.04 $\mathrm{h}^{-1}$; Fig. 1D). Addition of ammonium, glucose and DFAA increased the maximum bacterial abundance and bacterial growth rate compared to the control. In $\mathrm{NH}_{4}{ }^{+}\left(+\mathrm{NH}_{4}{ }^{+}\right)$and DFAA (+DFAA) amended treatments, however, bacterial abundance started to decrease before a constant level was reached (Fig. 1C).

\section{Dissolved free amino acids (DFAA)}

The initial DFAA concentration in the experiments ranged from 300 to $700 \mathrm{nM}$; we found no elevation of DFAA concentration due to filtration and preparation of the cultures. Concentrations of DFAA are naturally very high in the Delaware Bay (Coffin 1989, Keil \& Kirchman 1993). In both experiments DFAA con-
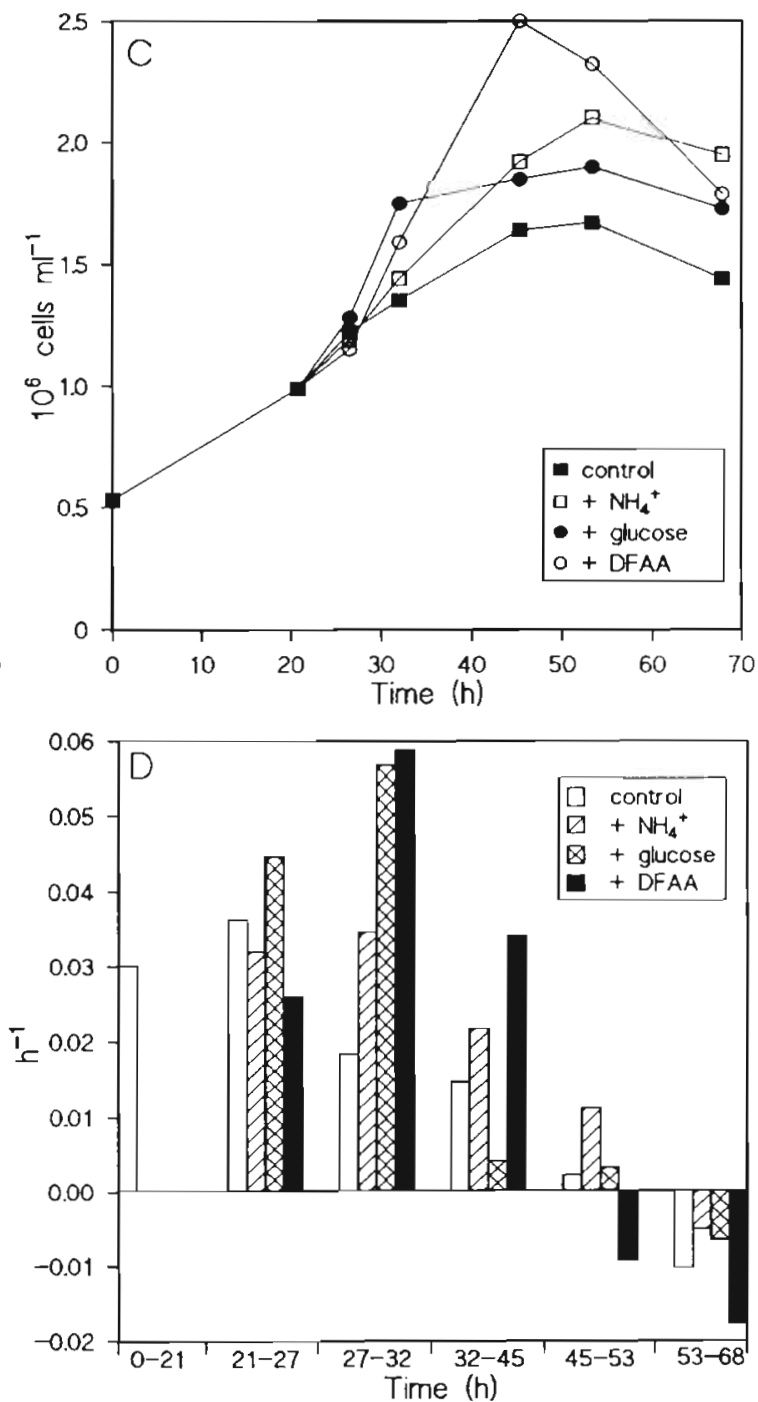

Fig. 1. Bacterial abundance and growth rate in (A, B) Expt 1 and (C, D) Expt 2 

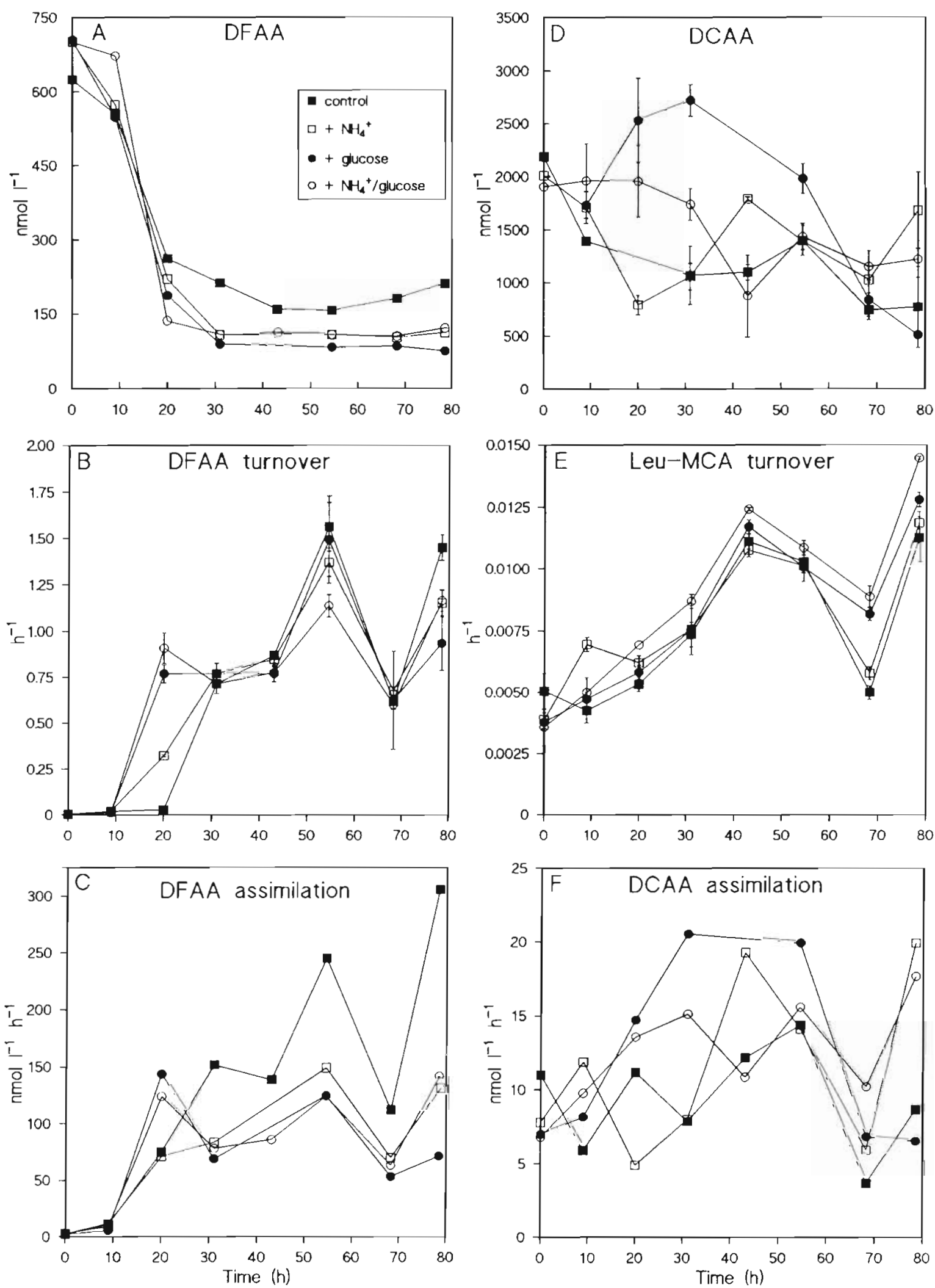

Fig. 2. Expt 1. (A) Concentration, (B) turnover and (C) assimilation rate of dissolved free amino acids; (D) concentratıon of dissolved combined amino acids (DCAA), (E) Leu-MCA turnover and (F) estimated DCAA assimilation rate 
centration decreased during the first 20 to $30 \mathrm{~h}$ to about 100 to $200 \mathrm{nM}$ (Figs. 2A \& 3A), and remained constant throughout the rest of the incubation. The DFAA added in Expt 2 was utilized $32 \mathrm{~h}$ after addition

\section{Dissolved combined amino acids (DCAA)}

The initial DCAA concentration in Expt 1 was approximately $2000 \mathrm{nM}$ and constituted $75 \%$ of the total pool of amino acids (Fig. 2D). In the control and $+\mathrm{NH}_{4}{ }^{+}$cultures, DCAA concentrations were reduced to about $1000 \mathrm{nM}$ during the first $31 \mathrm{~h}$. In glucoseenriched cultures DCAA remained constant or increased at the beginning of the incubation, followed by a decrease after $31 \mathrm{~h}$ (Fig. 2D).

The in situ DCAA concentration had decreased from 2000 to $1400 \mathrm{nM}$ between the 2 sampling dates and constituted $81 \%$ of total amino acids in Expt 2 (Fig. 3D). After decreasing to $1200 \mathrm{nM}$ during the first $21 \mathrm{~h}$, DCAA concentration tended to increase in all cultures in this experiment. After 32 h a decrease in DCAA concentration was observed in all cultures (Fig. 3D).

\section{DFAA assimilation and incorporation}

Respiration of ${ }^{3} \mathrm{H}$-amino acids did not vary significantly between cultures or during the incubation in any of the experiments; the averages were $43.5 \%$ $\pm 5.8 \%( \pm \mathrm{SD}, \mathrm{n}=8)$ and $50.1 \% \pm 7.5 \%(\mathrm{n}=5)$ of the assimilated ${ }^{3} \mathrm{H}$-amino acid mixture in Expts 1 and 2 , respectively. In the following discussion DFAA turnover and assimilation rates are based on total assimilation (i.e. incorporation + respiration) of ${ }^{3} \mathrm{H}$-labelled DFAA.

DFAA turnover increased in both experiments concomitant with increased bacterial abundance and peaked at 1.1 to $1.5 \mathrm{~h}^{-1}$ in Expt 1 and 0.7 to $1.0 \mathrm{~h}^{-1}$ in Expt 2 after about 50 h (Figs. 2B \& 3B). DFAA assimilation followed the turnover with maximum assimilation rates of $542 \mathrm{nmol} \mathrm{l}^{-1} \mathrm{~h}^{-1}$ in +DFAA and 100 to $300 \mathrm{nmol}$ $\mathrm{I}^{-1} \mathrm{~h}^{-1}$ in the other cultures (Figs. $2 \mathrm{C} \& 3 \mathrm{C}$ ).

\section{DCAA turnover and hydrolysis}

In both experiments Leu-MCA turnover were 2 orders of magnitude lower than DFAA turnover and ranged from $0.003 \mathrm{~h}^{-1}$ to $0.015 \mathrm{~h}^{-1}$ in Expts 1 and 2 (Figs. 2E \& 3E). DCAA hydrolysis was 1 order of magnitude lower than DFAA assimilation and ranged from 4 to $23 \mathrm{nmol} \mathrm{l}^{-1} \mathrm{~h}^{-1}$ (Figs. $2 \mathrm{~F} \& 3 \mathrm{~F}$ ).

\section{Ammonium concentration}

$\mathrm{NH}_{4}{ }^{+}$concentration decreased by about $2 \mu \mathrm{M}$ in control, glucose (+glucose) and ammonium $\left(+\mathrm{NH}_{4}{ }^{+}\right)$ amended cultures (Fig. 4A), while $\mathrm{NH}_{4}{ }^{+}$concentration in cultures with the addition of both ammonium and glucose $\left(+\mathrm{NH}_{4}{ }^{+} /\right.$glucose) decreased by $7.3 \mu \mathrm{M}$ over $43 \mathrm{~h}$ and then increased by $2.5 \mu \mathrm{M}$ (Fig. $4 \mathrm{~A}$ ). At the onset of Expt 2, the in situ $\mathrm{NH}_{4}{ }^{+}$concentration had decreased to $<0.3 \mu \mathrm{M}$, and decreased further to about the detection limit of the method (ca $0.10 \mu \mathrm{M}$ ) in control and +glucose incubations (Fig. 4B). In the $+\mathrm{NH}_{4}{ }^{+}$treatment the concentration decreased slightly after the ammonium addition, while enrichment with DFAA resulted in an increase of $4.03 \mu \mathrm{M}$ within $25 \mathrm{~h}$ after addition.

\section{$\mathrm{C}$ and $\mathrm{N}$ budget}

Bacterial $\mathrm{C}$ and $\mathrm{N}$ budgets were calculated separately for the exponential ( 0 to $20-30 \mathrm{~h}$ ) and stationary (20-30 to $45-55 \mathrm{~h}$ ) phases. We did not analyze the last period when bacterial abundance decreased. Contributions of DFAA and DCAA to bacterial C and N demand were calculated both from turnover of ${ }^{3} \mathrm{H}$ DFAA and Leu-MCA and from changes in concentrations of DFAA and DCAA over time. $C$ and N content of DFAA and DCAA were based upon the $\mathrm{C}$ and $\mathrm{N}$ content of individual amino acids.

In both experiments there was a substantial discrepancy between $\mathrm{C}$ and $\mathrm{N}$ incorporation estimated from ${ }^{3} \mathrm{H}$-DFAA uptake and from decreases in DFAA concentration. Apart from the first $20 \mathrm{~h}$ of Expt 1, during which DFAA assimilation rates agreed with rates of decrease in DFAA concentrations (Fig. 2A \& C), uptake rates of DFAA-N and DFAA-C exceeded the corresponding decreases in DFAA concentration by 200 to $400 \%$ during the exponential phase (Tables 1 to 4 ). Differences between the 2 estimates of DFAA uptake increased even more during the stationary phase, where DFAA concentrations remained relatively constant despite a progressive increase in ${ }^{3} \mathrm{H}$-DFAA uptake.

In Expt 1 net DFAA incorporation based on decreases in DFAA concentrations constituted 8 to $14 \%$ of bacterial $\mathrm{C}$ demand and 18 to $30 \%$ of their $\mathrm{N}$ demand during exponential growth; the greatest contribution of DFAA was observed in cultures without glucose additions (Tables 1 \& 2). In Expt 2 the decrease in DFAA concentrations could account for $14 \%$ of the $\mathrm{C}$ demand and $34 \%$ of the $\mathrm{N}$ demand during the first $21 \mathrm{~h}$ (Tables $3 \& 4$ ). Except for the + DFAA culture the contribution of DFAA to $C$ and $N$ demand decreased during the stationary phase in Expt 2 . 

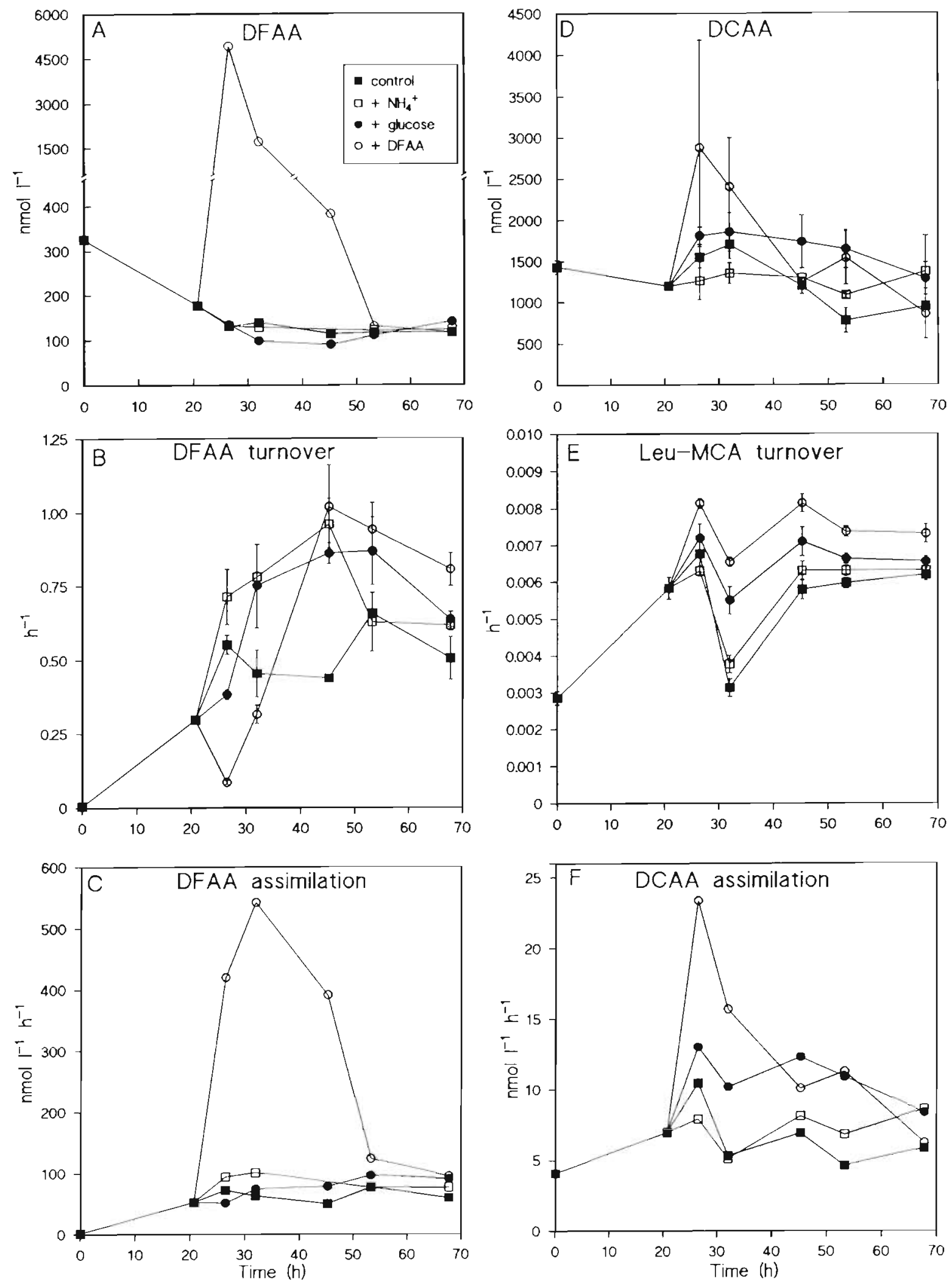

Fig. 3. Expt 2. (A) Concentration, (B) turnover and (C) assimilation rate of dissolved free amino acids; (D) concentration of dissolved combined amino acids (DCAA), (E) Leu-MCA turnover and (F) estimated DCAA assimilation rate 

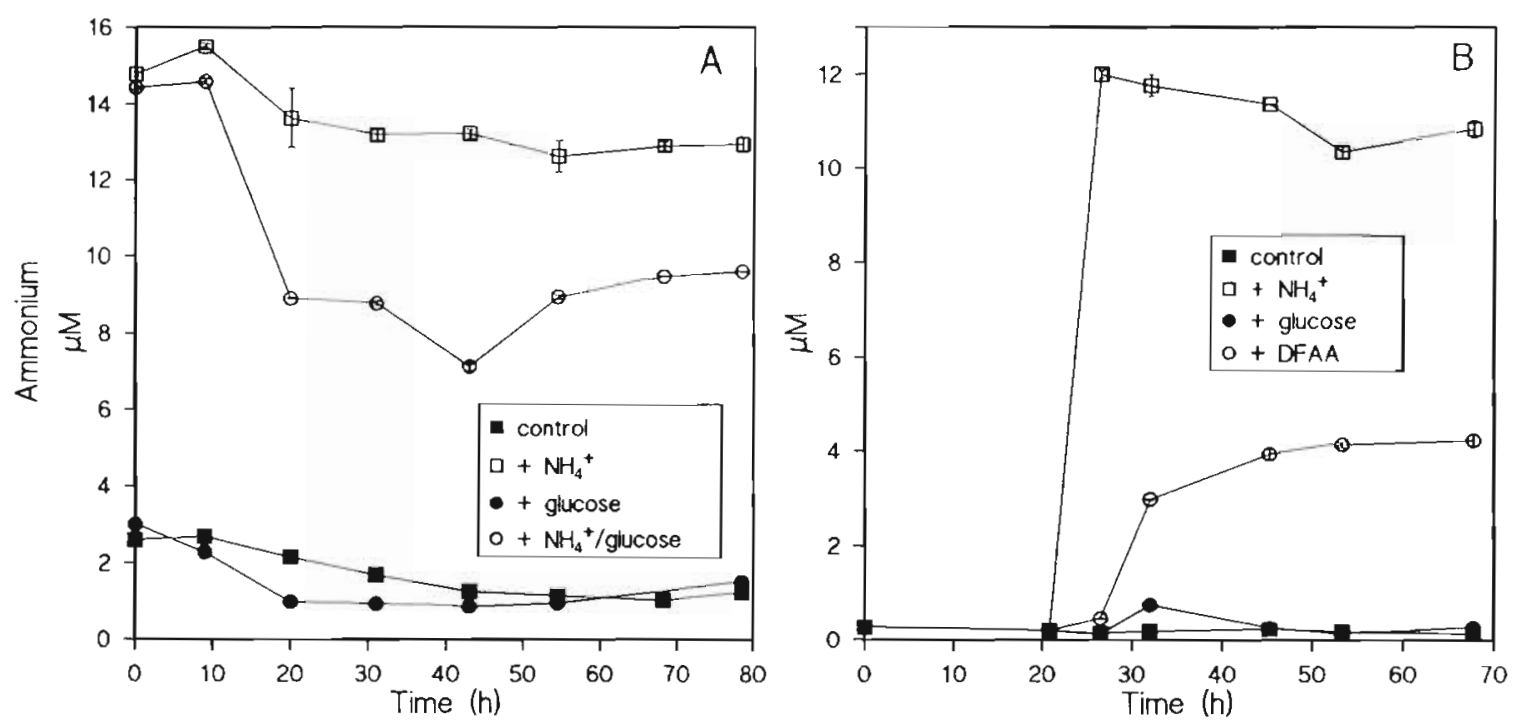

Fig. 4. Ammonium concentration in (A) Expt 1 and (B) Expt 2

Like DFAA uptake, we observed quite large differences between the 2 concurrent measurements of DCAA hydrolysis (Tables 1 to 4). Generally, estimates of DCAA hydrolysis based on decreases in DCAA concentration were larger than those obtained by LeuMCA hydrolysis. DCAA release, i.e. increases in DCAA concentration, was observed during part of the incubation in all cultures.

Based on the tracer approach, DCAA sustained 5 to $8 \%$ of the $\mathrm{C}$ demand and 10 to $16 \%$ of the $\mathrm{N}$ demand during the exponential phase in Expt 1 (Tables 1 \& 2). During the stationary phase the DCAA contribution increased to $23-43 \%$ and $46-85 \%$ of the $\mathrm{C}$ and $\mathrm{N}$ demand, respectively, with increasing importance in cultures without an ammonium addition. In Expt 2 DCAA sustained $10 \%$ and $24 \%$ of $\mathrm{C}$ and $\mathrm{N}$ demand, respectively, during the first $21 \mathrm{~h}$ (Tables 3 \& 4). During the stationary phase the importance of DCAA as an $\mathrm{N}$ source increased to $30 \%$ of $\mathrm{N}$ demand in the glucoseenriched culture, while it decreased to $13-17 \%$ in the other cultures.

Based on turnover of ${ }^{3} \mathrm{H}-\mathrm{DFAA}$ and Leu-MCA during exponential growth DFAA, DCAA and ammonium accounted for 37 to $62 \%, 4$ to $10 \%$ and 27 to

Table 1 Expt 1. Net uptake of $\mathrm{C}$ by incorporation of DFAA and DCAA compared to estimated bacterial net $\mathrm{C}$ demand during exponential and stationary phases

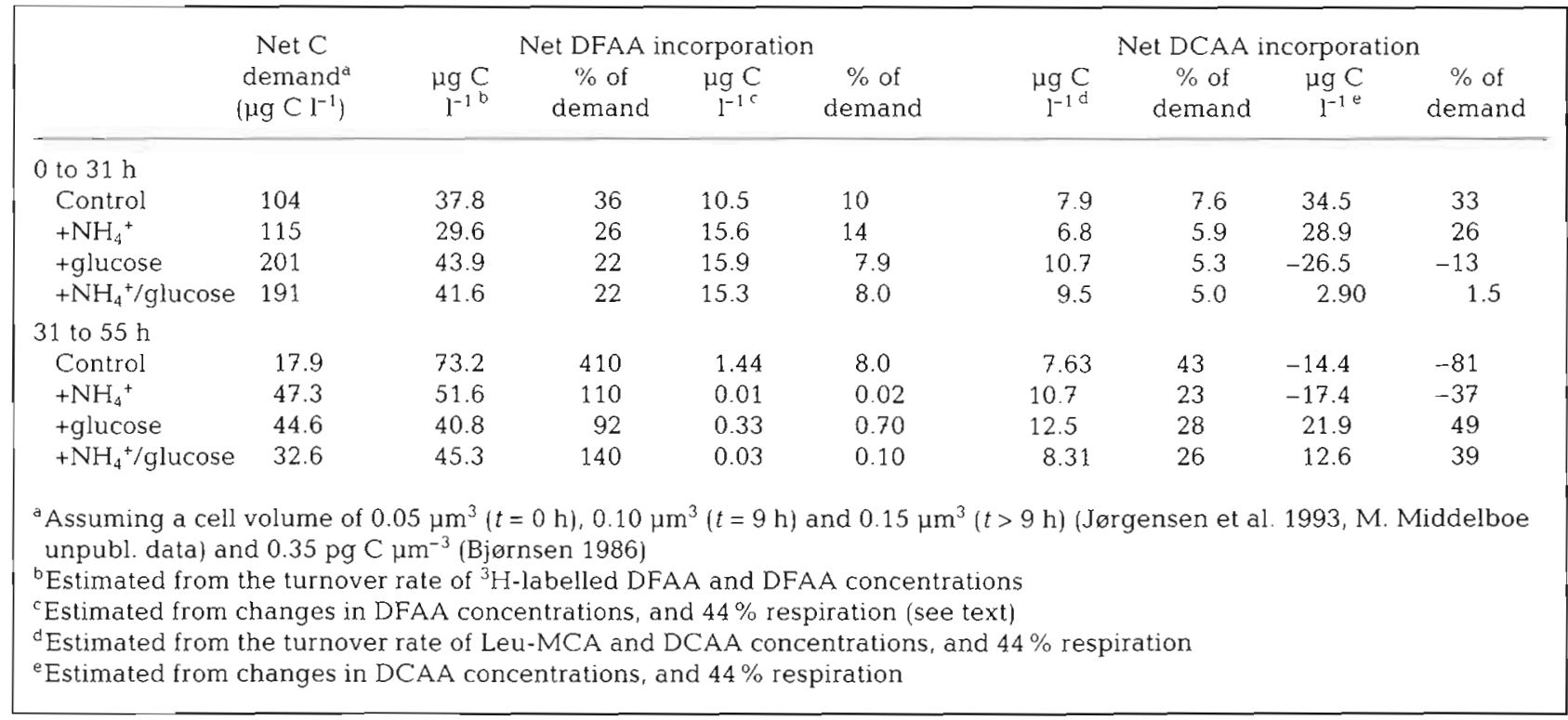


Table 2. Expt 1 Bacterial $\mathrm{N}$ uptake by incorporation of DFAA, DCAA and $\mathrm{NH}_{4}^{+}$, compared to estimated bacterial $\mathrm{N}$ demand during exponential and stationary phases

\begin{tabular}{|c|c|c|c|c|c|c|c|c|c|c|c|}
\hline & \multirow{2}{*}{$\begin{array}{c}\text { Net } N \\
\text { demand }^{a} \\
\left(\mu g \mathrm{Nl}^{-1}\right)\end{array}$} & \multicolumn{4}{|c|}{ DFAA incorporation } & \multicolumn{4}{|c|}{ DCAA incorporation } & \multicolumn{2}{|c|}{$\mathrm{NH}_{4}{ }^{+}$incorporation } \\
\hline & & $\underset{l^{-1 b}}{\lg N}$ & $\begin{array}{c}\% \text { of } \\
\text { demand }\end{array}$ & $\underset{l^{-1 C}}{\lg N}$ & $\begin{array}{c}\% \text { of } \\
\text { demand }\end{array}$ & $\begin{array}{r}\mu g N \\
l^{-1 d}\end{array}$ & $\begin{array}{c}\% \text { of } \\
\text { demand }\end{array}$ & $\underset{\mathrm{l}^{-1} \mathrm{e}}{\mathrm{Ng}}$ & $\begin{array}{c}\% \text { of } \\
\text { demand }\end{array}$ & $\lg _{l^{-1}} N$ & $\begin{array}{c}\% \text { of } \\
\text { demand }\end{array}$ \\
\hline \multicolumn{12}{|l|}{0 to $31 \mathrm{~h}$} \\
\hline Control & 30.3 & 28.2 & 93 & 6.4 & 21 & 4.7 & 16 & 23.0 & 76 & 12.7 & 42 \\
\hline$+\mathrm{NH}_{4}{ }^{+}$ & 33.5 & 22.7 & 68 & 10.1 & 30 & 4.2 & 13 & 17.3 & 52 & 22.4 & 67 \\
\hline +glucose & 58.7 & 32.6 & 56 & 10.8 & 18 & 6.5 & 11 & -8.43 & -14 & 28.8 & 49 \\
\hline$+\mathrm{NH}_{4}{ }^{+} /$glucose & 55.8 & 48.8 & 87 & 10.1 & 18 & 5.7 & 10 & 4.71 & 8.4 & 79.1 & 140 \\
\hline \multicolumn{12}{|l|}{31 to $55 \mathrm{~h}$} \\
\hline Control & 5.21 & 66.1 & 130 & 1.23 & 24 & 4.43 & 85 & -3.66 & -71 & 7.56 & 150 \\
\hline$+\mathrm{NH}_{4}{ }^{+}$ & 13.8 & 45.5 & 330 & -0.13 & -0.90 & 6.3 & 46 & -4.25 & -31 & 7.70 & 56 \\
\hline +glucose & 13.0 & 35.8 & 280 & 0.14 & 1.1 & 7.6 & 58 & 12.2 & 94 & -0.28 & -2.2 \\
\hline$+\mathrm{NH}_{4}{ }^{+} / g l u c o s e$ & e 9.49 & 44.9 & 470 & 0.01 & 0.12 & 4.6 & 49 & 5.02 & 53 & -2.38 & -25 \\
\hline $\begin{array}{l}{ }^{d} \text { Estimated from } \\
{ }^{b} \text { Estimated from } \\
{ }^{c} \text { Estimated from } \\
{ }^{d} \text { Estimated from } \\
{ }^{e} \text { Estimated from } \\
{ }^{\prime} \text { Estimated from }\end{array}$ & $\begin{array}{l}\text { a bacterial } \\
\text { n the turno } \\
\text { changes } \\
\text { a the turno } \\
\text { changes i } \\
\text { changes } i\end{array}$ & $\begin{array}{l}\text { demar } \\
\text { er rate } \\
\text { DFAA } \\
\text { er rate } \\
\text { DCAA } \\
\mathrm{NH}_{4}^{+}\end{array}$ & $\begin{array}{l}\text { d (Table } 1 \\
\text { f }{ }^{3} \mathrm{H} \text {-label } \\
\text { concentrat } \\
\text { f Leu-MC } \\
\text { concentra } \\
\text { oncentrati }\end{array}$ & $\begin{array}{l}\text { assum } \\
\text { led DF } \\
\text { tions } \\
\text { A and } \\
\text { tions } \\
\text { ons }\end{array}$ & $\begin{array}{l}\text { ing a mola } \\
\text { A and DF } \\
\text { CAA con }\end{array}$ & $\begin{array}{l}\text { N ratio } \\
\text { concent } \\
\text { rations }\end{array}$ & $\begin{array}{l}4 \text { (Lee } 8 \\
\text { ations }\end{array}$ & Fuhrn & an 1987) & & \\
\hline
\end{tabular}

Table 3. Expt 2. Net uptake of $\mathrm{C}$ by incorporation of DFAA and DCAA compared to estimated bacterial net $\mathrm{C}$ demand during exponential and stationary phases

\begin{tabular}{|c|c|c|c|c|c|c|c|c|c|}
\hline & \multirow{2}{*}{$\begin{array}{c}\text { Net C } \\
\text { demand } \\
\left(\mu g C^{-1}\right)\end{array}$} & \multicolumn{4}{|c|}{ Net DFAA incorporation } & \multicolumn{4}{|c|}{ Net DCAA incorporation } \\
\hline & & $\underset{l^{-2}}{\operatorname{mg}} \mathrm{C}$ & $\begin{array}{c}\% \text { of } \\
\text { demand }\end{array}$ & $\underset{I^{-1 c}}{\mu g C}$ & $\begin{array}{c}\% \text { of } \\
\text { demand }\end{array}$ & $\underset{1^{-1} d}{\mu g}$ & $\begin{array}{c}\% \text { of } \\
\text { demand }\end{array}$ & $\underset{I^{-1}}{\mu \mathrm{g} C}$ & $\begin{array}{c}\% \text { of } \\
\text { demand }\end{array}$ \\
\hline 0 to $21 \mathrm{~h}$ & \multicolumn{9}{|c|}{ - } \\
\hline Control & 25.4 & 10.6 & 42 & 3.56 & 14 & 2.50 & 10 & 5.63 & 22 \\
\hline \multicolumn{10}{|l|}{21 to $45 \mathrm{~h}$} \\
\hline Control & 51.5 & 31.1 & 60 & 1.12 & 2.2 & 4.0 & 7.8 & -1.65 & -3.2 \\
\hline$+\mathrm{NH}_{4}^{+}$ & 66.2 & 44.0 & 67 & 0.44 & 0.7 & 3.9 & 5.9 & -5.74 & -8.7 \\
\hline +glucose & 62.5 & 34.7 & 56 & 1.53 & 2.4 & 7.0 & 11 & -39.9 & -64 \\
\hline+ DFAA & 96.5 & 315 & 330 & 142 & 150 & 10.0 & 10 & -10.6 & -11 \\
\hline $\begin{array}{l}\text { assuming } \\
\text { unpubl. da } \\
{ }^{\mathrm{b}} \text { Estimated } \\
{ }^{\mathrm{c} E s t i m a t e d} \\
{ }^{\mathrm{d} E s t i m a t e d} \\
{ }^{e} \text { Estimated }\end{array}$ & $\begin{array}{l}\text { 1 volume of } \\
\text { nd } 0.35 \mathrm{pg} \\
\text { the turnove } \\
\text { changes in } \\
\text { the turnove } \\
\text { changes in }\end{array}$ & $\begin{array}{l}\mu \mathrm{m}^{3}(t \\
\mathrm{m}^{-3} \text { (Bjø } \\
\text { te of }{ }^{3} \mathrm{H} \\
\text { AA conc } \\
\text { ate of Le } \\
\text { AA con }\end{array}$ & $\begin{array}{l}(\mathrm{h}), 0.10 \mu \\
\text { sen } 1986) \\
\text { abelled DF } \\
\text { atrations, a } \\
\text { MCA and } \\
\text { ntrations, a }\end{array}$ & $\begin{array}{l}{ }^{3}(t=9 \mathrm{~h} \\
\text { A and D } \\
\text { d } 50 \% \text { re } \\
\text { CAA cor } \\
\text { d } 50 \% \text { r }\end{array}$ & $\begin{array}{l}\text { nd } 0.15 \\
\text { A concent } \\
\text { iration (se } \\
\text { entrations, } \\
\text { oiration }\end{array}$ & $\begin{array}{l}9 \mathrm{~h})(\mathrm{J} \emptyset \\
0 \% \text { resp }\end{array}$ & ensen et al & 1993, M & liddelboe \\
\hline
\end{tabular}

$59 \%$ of total $\mathrm{N}$ uptake (DFAA + DCAA $+\mathrm{NH}_{4}{ }^{+}$), respectively, in Expt 1. The importance of $\mathrm{NH}_{4}^{+}$ increased at the expense of DFAA in $\mathrm{NH}_{4}{ }^{+}$-enriched cultures. In Expt 2 the corresponding values were 78, 14 and $8 \%$ of total $N$ uptake, respectively, during the initial $21 \mathrm{~h}$.

Fig, 5 presents an overview of the contributions of DFAA, DCAA and $\mathrm{NH}_{4}{ }^{+}$to bacterial $\mathrm{N}$ demand during different stages of the incubations. In both experiments there appeared to be a shift in the main bacterial DON (dissolved organic $N$ ) source from DFAA during the first $20 \mathrm{~h}$ towards a dominance of DCAA at the end of the incubations. Especially in glucose-enriched cultures not supplied with $\mathrm{NH}_{4}{ }^{+}$, DCAA constituted an important $N$ source for the bacteria during the stationary phase. The DFAA-enriched culture deviated from this general pattern since DFAA in this culture constituted the single most important $N$ source.

In Expt 1, $\mathrm{NH}_{4}{ }^{+}$was the dominant $\mathrm{N}$ source in all the enriched cultures during the first $20 \mathrm{~h}$. $\mathrm{NH}_{4}{ }^{+}$then decreased in importance and eventually was regenerated during the last period. In contrast, the contribu- 

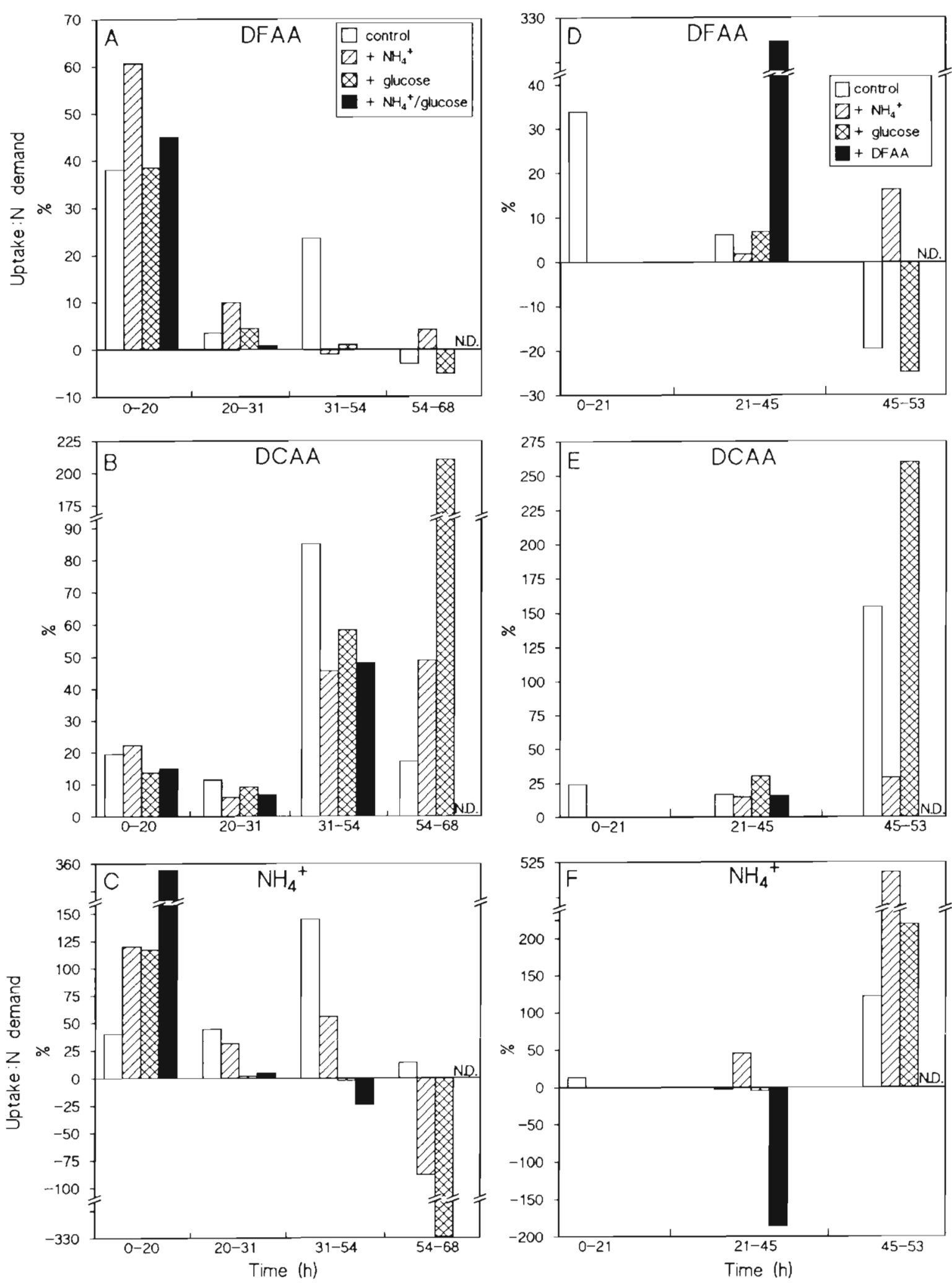

Fig. 5. Uptake:demand ratio of $\mathrm{N}$ supported by DFAA, DCAA and $\mathrm{NH}_{4}{ }^{+}$, respectively, in (A. to C) Expt 1 and (D to F) Expt 2 Values are based on Leu-MCA turnover and changes in DFAA and ammonium concentration 
explanation for the observed disparity (Tables 1 to 4 ; Jørgensen et al. 1993), assuming that products from DCAA hydrolysis actually enter the bulk pool of DFAA prior to assimilation.

As an additional explanation we suggest that DFAA are recycled efficiently within the bacterial assemblage. DFAA and DCAA may be released from the bacteria by cell lysis, flagellate grazing and viral infection, and utilized by other bacteria. This hypothesis was supported by the fact that during the first 10 to $20 \mathrm{~h}$, DFAA assimilation was equal to the sum of the decrease in DFAA and the estimated release of DFAA from DCAA hydrolysis, and only at the end of the exponential phase did recycling of DFAA apparently become an increasingly important part of the DFAA flux. During substrate limitation, bacteria thus seem able to sustain a 'regenerated' production based on recycling of bacterial biomass. This may have important consequences for the interpretation of bacterial growth in batch cultures. Changes in cell counts or biomass may seriously underestimate gross production and may not be comparable to incorporation rates of amino acids and thymidine even during short incubations (e.g. 20 h). Consequently, bacterial recycling of organic compounds may bias measurements of conversion factors which relate bacterial thymidine or leucine incorporation to cell production. Our observations may explain why conversion factors measured in batch cultures frequently have been higher than expected, based on theoretical calculations, especially when those factors are calculated from changes in incorporation rates over time (e.g. Kirchman et al. 1982).

We calculated bacterial DCAA utilization from the decrease in DCAA concentrations in order to assess the applicability of Leu-MCA hydrolysis in estimating total DCAA hydrolysis. Such a comparison is, however, not straightforward, since DCAA concentrations increased during part of the experiments. The comparison was limited to periods of decreasing DCAA, and thus only reflected net removal of DCAA during those periods. From a total of 23 periods in the 2 experiments where it was possible to compare the 2 estimates of DCAA hydrolysis, we found that the Leu-MCA based estimate on average constituted $42 \% \pm 37 \%( \pm \mathrm{SD}, \mathrm{n}=$ 23) of DCAA assimilation based on decreases in DCAA concentration. In the Leu-MCA based estimate we assumed all the measured DCAA to be potential substrates for the aminopeptidase. Since only a part of the measured DCAA may constitute a substrate for bacterial extracellular hydrolysis (Keil \& Kirchman 1993), rates of DCAA hydrolysis based on Leu-MCA are probably overestimated. Moreover, since a decrease in DCAA concentration only reflected net removal by the bacteria it represented a minimum estimate of DCAA hydrolysis. Consequently, our results indicate that hydrolysis of Leu-MCA, when used in tracer concentrations, may underestimate actual protein hydrolysis. Although aminopeptidases as detected by Leu-MCA are expected to be important in processing of natural peptides (Hoppe et al. 1988), the model substrate obviously did not fully reflect total protein hydrolysis in the cultures. Part of the decrease in DCAA concentration may, however, be ascribed to uptake of small peptides (<6 amino acids), which can be utilized without exoproteolysis (Payne 1980)

Utilization of DCAA as estimated from Leu-MCA hydrolysis was generally of minor importance during exponential growth in Expt 1 (Tables 1 \& 2), and it accounted for at most $25 \%$ of the $\mathrm{N}$ demand in Expt 2 (Table 4). Based on the decrease in DCAA concentration, DCAA utilization in Expt 1 appeared to be repressed by the glucose addition, since DCAA utilization was delayed in tglucose and $+\mathrm{NH}_{4}{ }^{+} /$glucose in contrast to control and $+\mathrm{NH}_{4}{ }^{+}$cultures (Fig. 2D, Tables $1 \& 2$ ). The importance of DCAA as an N source increased during the stationary phase, and DCAA was the dominant $\mathrm{N}$-source for bacteria growing without an $\mathrm{NH}_{4}{ }^{+}$addition in Expt 1 (Table 2, Fig. 5). Similarly, DCAA was the most important $\mathrm{N}$-source in the +glucose culture during the stationary phase in Expt 2 (Table 4, Fig. 5). The results indicate that DCAA may contribute significantly to bacterial $\mathrm{C}$ and $\mathrm{N}$ demand when easily available $C$ and $N$ compounds are low, consistent with the conclusions of previous studies (Keil \& Kirchman 1991, 1993, Simon \& Rosenstock 1992, Kroer et al. 1994). Moreover, DCAA concentration measurements demonstrated that DCAA were released from the bacteria, especially during the stationary phase (Figs. 2D \& 3D). This DCAA release is consistent with our hypothesis about DFAA release during the stationary phase. In contrast to DFAA, DCAA were not taken up as fast as DFAA and therefore accumulated periodically.

During exponential growth DFAA + DCAA + $\mathrm{NH}_{4}{ }^{+}$ sustained 109 to $170 \%$ and 71 to $78 \%$ of the estimated $\mathrm{N}$-demand in cultures with and without addition of $\mathrm{NH}_{4}{ }^{+}$, respectively (Tables 2 \& 4). Values $<100 \%$ may be explained by the utilization of other $\mathrm{N}$ sources like $\mathrm{NO}_{3}{ }^{-}$as demonstrated by Jørgensen et al. $(1993,1994)$. Estimates of bacterial $\mathrm{N}$ uptake in excess of their estimated demand have previously been observed (Keil \& Kirchman 1991, Jørgensen et al. 1994, Kroer et al. 1994). Although this phenomenon in some cases may be partly explained by the likely interference of DFAA recycling, unbalanced $\mathrm{N}$ budgets appear to be a general feature of bacterial growth in batch cultures. Kroer et al. (1994) suggested the release of $N$ compounds like methylamines and urea as a possible explanation for the $\mathrm{N}$ imbalance since they did not find changes in bacterial C:N ratio during excessive $\mathrm{N}$ uptake. More- 
over, bacterial nitrification of $\mathrm{NH}_{4}{ }^{+}$may be an important process in batch experiments (Bronk \& Glibert 1993, Sondergaard \& Middelboe 1995), causing an overestimation of bacterial $\mathrm{NH}_{4}{ }^{+}$uptake. Finally, our comparisons of bacterial nutrient uptake and demand are associated with some uncertainty since estimates of bacterial $\mathrm{C}$ and $\mathrm{N}$ demand rely on the use of theoretical conversion factors to calculate cell $\mathrm{C}$ and $\mathrm{N}$ content from cell abundance.

The DFAA source in batch cultures is limited to a small concentration of DFAA present at the time of sampling in contrast to productive natural systems, characterized by a constant input of DFAA from various sources. The rapid utilization of DFAA and ammonium and the shift towards utilization of DCAA at the end of the incubations support the opinion that bacterioplankton growth in natural systems is generally based on a close coupling between supply and uptake of readily available organic and inorganic nutrients, and that polymeric compounds may provide important $\mathrm{C}$ and $\mathrm{N}$ sources during periods of low input of labile substrates (Coffin et al. 1993, Middelboe \& Søndergaard 1993, 1995). Going from productive coastal systems to oligotrophic oceanic waters, the contribution of DCAA to bacterial $C$ demand would probably increase, since bacterial hydrolysis of POC (particulate organic C) and DCAA may provide the main source of DFAA in such low-productive systems (Hoppe et al. 1993).

Acknowledgements. The study was supported by a Danish Natural Sciences Research Council grant to M.M., by an NSF grant to D.L.K., and by a Danish Research Academy grant to N.H.B. We thank Prof. Morten Sendergaard and 3 anonymous reviewers for valuable comments on the manuscript, and Dr N. O. G. Jørgensen for measurements of amino acid concentrations.

\section{LITERATURE CITED}

Billen G (1991) Protein degradation in aquatic environments In: Chróst RJ (ed) Microbial enzymes in aquatic environments. Springer-Verlag, New York, p 123-143

Bjørnsen PK (1986) Automatic determination of bacterioplankton bromass by image analysis. Appl environ Microbiol 51:1199-1204

Bronk DA, Glibert PM (1993) Contrasting patterns of dissolved organic nitrogen release by two size fractions of estuarine plankton during a period of rapid $\mathrm{NH}_{4}{ }^{+}$con. sumption and $\mathrm{NO}_{2}{ }^{-}$production. Mar Ecol Prog Ser 96 $291-299$

Coffin RB (1989) Bacterial uptake of dissolved free and combined amino acids in estuarine waters. Limnol Oceanogr 34(3):531-542

Coffun RB, Connolly JP, Harris PS (1993) Availability of dissolved organic carbon to bacterioplankton examined by oxygen utllization. Mar Ecol Prog Ser 101:9-22

Hobbie JE, Daley RJ, Jasper S (1977) Use of Nuclepore filters for counting bacteria by epifluorescence microscopy. Appl environ Microbiol 33:1225-1228

Hoppe HG, Ducklow H, Karrasch B (1993) Evidence for dependency of bacterial growth on enzymatic hydrolysis of particulate organic matter in the mesopelagic ocean. Mar Ecol Prog Ser 93:277-283

Hoppe HG, Kim SJ, Gocke K (1988) Microbial decomposition in aquatic environments: combined process of extracellular enzyme activity and substrate uptake. Appl environ Microbiol 54(3):784-790

Jørgensen NOG, Kroer N, Coffin RB (1994) Utilization of dissolved nitrogen by heterotrophic bacterioplankton: effect of substrate $\mathrm{C} / \mathrm{N}$ ratio. Appl environ Microbiol 60(11): 4124-4133

Jorgensen NOG, Kroer N, Coffin RB, Yang XH, Lee C (1993) Dissolved free amino acids, combined amino acids, and DNA as sources of carbon and nitrogen to marine bacteria. Mar Ecol Prog Ser 98:135-148

Keil RG, Kirchman DL (1991) Contribution of dissolved free amino acids, and ammonium to the nitrogen requirements of heterotrophic bacterioplankton. Mar Ecol Prog Ser 73: $1-10$

Keil RG, Kirchman DL (1993) Dissolved combined amino acids: chemical form and utilization by marine bacteria. Limnol Oceanogr 38(6): 1256-1270

Kirchman DL, Ducklow HW, Mitchell R (1982) Estimates of bacterial growth from changes in uptake rates and biomass. Appl environ Microbiol 44:1296-1307

Kroer $N$, Jørgensen NOG, Coffin RB (1994) Utilization of dissolved nitrogen by heterotrophic bacterioplankton: a cross-ecosystem comparison. Appl environ Microbiol 60 (11): $4116-4123$

Lee S, Fuhrman JA (1987) Relationships between biovolume and biomass of naturally derived marine bacterioplankton. Appl environ Microbiol 53(6): 1298-1303

Lindroth P, Mopper K (1979) High performance liquid chromatographic determinations of subpicomolar amounts of amino acids by precolumn fluorescence derivatization with o-phthaldialdehyde. Analyt Chem 51:1667-1674

Middelboe $M$, Sendergaard $M$ (1993) Bacterioplankton growth yield: seasonal variations and coupling to substrate lability and $\beta$-glucosidase activity. Appl environ Microbiol 59(11):3916-3921

Middelboe $M$, Søndergaard M (1995) Concentration and bacterial utilization of sub-micron particles and dissolved organic carbon in lakes and a coastal area. Arch Hydrobiol 133:129-147

Payne JW (1980) Microorganisms and nitrogen sources Wiley, New York

Rosenstock B, Simon M (1993) Use of dissolved combined and free amino acids by planktonic bacteria in Lake Constance. Limnol Oceanogr 38(7):1521-1531

Simon M. Rosenstock B (1992) Carbon and nitrogen sources of planktonic bacteria in Lake Constance studied by the composition and isotope dilution of intracellular amino acids. Limnol Oceanogr 37(7):1496-1511

Søndergaard M, Middelboe M (1995) A cross-system analysis of labile dissolved organic carbon (DOC $C_{L}$ ). Mar Ecol Prog Ser 118:283-294

Suttle CA, Chan AM, Fuhrman JA (1991) Dissolved free amino acids in the Sargasso Sea: uptake and respiration rates, turnover times, and concentrations. Mar Ecol Prog Ser 70:189-199

Tupas L, Koike I (1990) Amino acid and ammonium utilization by heterotrophic marine bacteria grown in enriched seawater. Limnol Oceanogr 35(5):1145-1155

Manuscript first received: February 20, 1995

Revised version accepted: May 31, 1995 